$1-1-1995$

\title{
The End of Roman Juristic Writing
}

\author{
Alan Watson \\ University of Georgia School of Law, wawatson@uga.edu
}

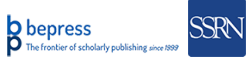

\section{Repository Citation}

Alan Watson, The End of Roman Juristic Writing (1995),

Available at: https://digitalcommons.law.uga.edu/fac_artchop/463

This Article is brought to you for free and open access by the Faculty Scholarship at Digital Commons @ University of Georgia School of Law. It has been accepted for inclusion in Scholarly Works by an authorized administrator of Digital Commons @ University of Georgia School of Law. Please share how you have benefited from this access For more information, please contact tstriepe@uga.edu. 


\title{
THE END OF ROMAN JURISTIC WRITING
}

\author{
Alan Watson*
}

I first met Reuven Yaron in 1958, and we immediately became fast friends. The friendship with him and Shoshana has deepened over the years, and will continue. He and I have frequently read one another's draft papers. I thank him for many years of intellectual and emotional support, and hope he will take pleasure in this offering that he has had no possibility of criticising in advance.

The traditional date for the end of classical Roman law is 235 when the emperor Alexander Severus was murdered, or slightly later with the death of Modestinus, the last of the great known jurists. Thereafter, few original juristic books were written, ${ }^{1}$ and it is widely but not universally believed that a decline in legal standards began almost at once. ${ }^{2}$

For many scholars there seems to exist a connection, sometimes simply implicit, between the failure of jurists to write new books, and a decline in legal standards. I should like to suggest there was a different reason for jurists ceasing to write new law books. They had already written them all! The claim that for the period, say fifty years, after around 235, all the law books had already been written seems extreme, but is easy to substantiate.

The Roman jurists traditionally divided their private law into civil law, ius civile, and praetorian edictal law, ius honorarium. The ius honorarium derived from the praetors' Edicts, especially that of the urban praetor. The Edict of that praetor, and presumably that also of the pergrine praetor was put into its final form on the instructions of the emperor Hadrian (117-138). Thereafter no changes were possible. The Edict was the subject of juristic writing, culminating in the massive commentaries of Paul in 80 books and of Ulpian in 83 books. These jurists were distinguished not only by their abilities but by their bureau-

* Ernest P. Rogers Professor of Law, University of Georgia.

1 The main exception is Hermogenianus, Iuris epitomae.

2 On the subject see, e.g., T. Honoré, "Conveyances of Land and Professional Standards in the Later Empire", in New Perspectives in the Roman Law of Property, P. Birks, ed. (Oxford, 1989) $137 \mathrm{ff}$. 
cratic careers. Paul was assessor to Papinian when he was the praefectus praetorio, belonged to the emperor's consilium, held the office a memoria, and himself became the praetorian prefect. ${ }^{3}$ Ulpian had a similar career, also being assessor to Papinian and reaching the same office of praetorian prefect, before he was murdered by the praetorian guard before the middle of $224 .{ }^{4}$

When Ulpian and Paul were writing, the Edict had been unchanged for a century. In between, much had been written on it, whether in commentaries on the Edict ${ }^{5}$ or in works on the civil law, or on a particular branch of law, or in books of answers to difficult issues. After Ulpian and Paul's huge commentaries, which would set out and discuss previous views, there could be no scope for further full-scale commentaries covering the same ground. No jurist could write a commentary settling disputed issues - that was not the way the system worked. No machinery existed to resolve disputes among the jurists; hence, centuries later, Justinian's Quinquaginta Decisiones were issued to settle points which had been left unresolved. The most that a jurist could usefully do by writing on the Edict would be to proffer new solutions or arguments on some disputed points. But here the reputation of Paul and Ulpian, deriving in part from their exalted positions, would deter all but the boldest or highest-placed.

There is still more to the issue. The Edict had been deliberately finalized under Hadrian because he and/or his advisors had decided that the Edict was no longer a fruitful source of law. And, indeed, the Edict had long ceased to be much used for making innovations. Further, no later emperor reversed Hadrian's decision and had legal changes made by the Edict. This tells us various things, but especially that there was no strongly held belief that interpretational disputes could be settled, and the law improved, by modifying the wording of an edict or by adding a clause. The grand lines had long been drawn.

3 See W. Kunkel, Herkunft und soziale Stellung der römischen Juristen, (Graz., 2nd ed., 1967) 244.

4 See Kunkel, Herkunft, at 245ff;; for the date of his murder see P. Oxy. 2565; J. Modrzejewski and T. Zawadzki, "La date de la mort d'Ulpien et la Préfecture du Prétoire au début du règne d'Alexandre Sévère" (1967) 45 Revue Historique de Droit Français et Étranger 565ff.; Richard Bauman, "The Death of Ulpian, the Irresistible Force and the Unmovable Object" (1995) 112 Zeitschrift der Savigny Stiftung 385ff.

5 Furius Anthianus had 5 books on the Edict; only 10 books of Gaius on the Edict were found by Justinian's Digest compilers, but he had also written 37 books on the provincial Edict. 
The ius civile derived from the Twelve Tables and subsequent statutes, and juristic opinions. Quintus Mucius Scaevola (died 82 B.C.) was the first to set out the civil law generatim in his Ius Civile in 18 books. ${ }^{6}$ His work was used as a model by Sabinus (active under Tiberius) for his commentary, Ius Civile, in three books. Sabinus' Ius Civile in its turn became the model for the great commentaries on the civil law, entitled ad Sabinum, 'On Sabinus': of Pomponius (active from the time of Hadrian to the joint reign of Marcus Aurelius and Lucius Verus (161-169)) in 35 books; of Paul in 16 books; and of Ulpian in 51 books. But after the death of Claudius in 54, Emperors had virtually stopped issuing statutes on private law. ${ }^{7}$ Jurists routinely cannibalized each others' works so it is not surprising that not a single fragment of Sabinus' Ius Civile survives in Justinian's Digest, though he is frequently cited, and will be reported but unacknowledged in other texts. These great commentaries on the civil law, like those on the Edict, proffered, discussed and evaluated the opinions of previous jurists. On the appearance of these large-scale commentaries, what reason could any jurist have in writing another? The answer is none, unless, as was not the case (as we shall see), the law was in a state of flux because of a flood of innovating imperial rescripts.

The commentaries ad Edictum and ad Sabinum did not, by any means, exhaust the writings of the jurists on private law. Their books took many forms. There were treatises on a particular branch of law. A notable example is the writing on fideicommissa, trusts: 16 books by Maecian, 7 by Valens, 6 by Ulpian, 5 by Pomponius, and 3 by Paul. The emphasis on this subject results from the inordinate capacity of testators to express their intentions ambiguously, and the large number of books betrays the competitiveness of the jurists in advancing their interpretations. But though the capacity of testators to be unclear or make mistakes is infinite, their ambiguities and errors tend to be repetitive. The law of diminishing returns means that after a certain point there is little purpose in writing yet another commentary, especially because the basic law had not changed. I suggest that after Paul and Ulpian's books on fideicommissa that point had been reached. There were also writings on a particular statute. The writings entitled de Adulteriis are of this type, being largely commentaries on Augustus' lex

6 D. 1.2.1.41.

7 This appears very clearly from G. Rotondi, Leges publicae populi romani (Milan, 1922) $468 \mathrm{ff}$. 
Iulia de adulteriis coercendis: Papinian had two books, plus a separate sole book, Paul had 3, Ulpian had 5. When we recall that the making of private law by legislation had virtually died out by 54 A.D., and had not been much used anyway (after the Twelve Tables), what new could be said about a statute that would prompt the writing of even a single volume on the subject?

But for our present purposes perhaps the most interesting type of book was collections of replies usually of a single jurist to knotty questions. The earliest example is from the late republic, the Digesta of Alfenus Varus, giving the replies of himself and his master, Servius. The genre continues through the outstanding Digesta of Julian in 90 books $^{8}$ to the triumphant finale of Papinian's Responsa in 19 books and Quaestiones in 37 books. From Roman times Papinian has usually been regarded as the greatest of the jurists. ${ }^{9}$ One strand of modern thought even is that Papinian is over-subtle. ${ }^{10} \mathrm{He}$ was interested in exploring the most difficult questions. Given his reputation as a jurist and his high office - he, too, as I mentioned, was praetorian prefect - it would be a daunting task for any subsequent jurist to publish a collection of replies. Comparisons would inevitably be made.

The argument is, of course, that at the time that Papinian, Paul and Ulpian were working, the Edict and legislation had long ceased to be sources of new law, and that they had been written upon repeatedly and exhaustively; that it was difficult for jurists to create new law because there was no machinery to resolve disputes between them; and that top jurists in any event had discussed in minute detail the most abstruse legal issues. The centuries, normally regarded as that of classical law, from Augustus to 235, were a period more of refinement than of innovation.

None of the above would hold true if, in the absence of Edict or statute, the emperors of the classical period and the half century thereafter busied themselves by making new law by rescripts. But this is not the case. The majority of rescripts quoted or referred to in the writings of the jurists are not innovatory, but restate existing law. The replies are often to what the jurists would have regarded as clear-cut cases, sometimes to complicated issues, but few change the law in a significant

8 See, e.g., F. Schulz, History of Roman Legal Science (Oxford, 1946) $229 \mathrm{f}$.

9 Witness his role in the Valentinian Law of Citations: C. Th. 1.4.3.

10 See, e.g., F. Brandsma, "Publiciana Rescissoria, or is Papinian 'zu spitz", (1992) 5 Subseciva Groningana 41ff. 
way. ${ }^{11}$ Subsequently, in the half-century of chaos until the arrival of Diocletian the imperial chancellery continued to function. An examination of the rescripts from the end of that period, of Probus (276-282) and of the father and sons, Carus, Carinus and Numerianus (282-284) shows little innovation and little decline in standards. ${ }^{12}$ The jurists in the half century after Ulpian still had little incentive to write books.

I hope it will not be urged against my thesis that the Bible was established as a fixed canon many centuries ago, and that books on it have never ceased to appear. Religion is a very different matter than law. In the first place, it excites much deeper emotions: the correct view may lead to salvation or nearness to God. Interpretation of details has greater significance. It is also much less tangible. Then, the aim of many theological writers is not to describe what is or what should be, but conversion. Again, much theological writing is aimed at a much wider audience. The Roman jurists - who were not law reformers - when they wrote to impress, wrote only for their fellow jurists. They were not trying to bring law closer to the people. Further, the only jurists whose voice would be listened to would be those living and working in the upper reaches of society. A jurist could not hope to attract a following simply because of charisma or personal power of persuasion. There could be no saints among the jurists. Lastly, the jurists were not interested in creating an ideal system or a law for all time. They had to proffer solutions, opinions, that could be followed in courts in the here and now. That puts great pressure upon ingenuity. Of course, jurists could offer new solutions or arguments but not enough, given the lack of new law proceeding from the state, to write whole books after the great and massive tomes of Papinian, Paul, Ulpian, and others.

11 The texts in the Digest are conveniently collected in G. Gualandi, Legislazione imperiale e giurisprudenza (Milan, 1963).

12 On the rescripts of these emperors see A. Watson, Legal Origins and Legal Change (London, 1991) 45ff, 61ff. 